\title{
A New Tomato-Infecting Tospovirus from Iran
}

\author{
Afshin Hassani-Mehraban, Janneke Saaijer, Dick Peters, Rob Goldbach, and Richard Kormelink
}

Laboratory of Virology, Wageningen University, Binnenhaven 11, 6709 PD Wageningen, the Netherlands. Accepted for publication 10 March 2005.

\begin{abstract}
Hassani-Mehraban, A., Saaijer, J., Peters, D., Goldbach, R., and Kormelink, R. 2005. A new tomato-infecting tospovirus from Iran. Phytopathology 95:852-858.

A new tospovirus species serologically distinct from all other established

posed. The S RNA of this virus was cloned and its 3,061 nucleotide long sequence showed features characteristic for tospoviral S RNA segments. The nucleocapsid $(\mathrm{N})$ protein with a predicted $\mathrm{Mr}$ of $30.0 \mathrm{kDa}$ showed closest relationship to the $\mathrm{N}$ protein of Iris yellow spot virus $(74 \%$ sequence identity).
\end{abstract} tospoviruses was found in tomato in Iran. Typical disease symptoms observed include necrotic lesions on the leaves and yellow ring spots on the fruits, hence the name Tomato yellow ring virus (TYRV) was pro-
Additional keywords: Bunyaviridae, immunocapture RT-PCR, taxonomy.
Tospoviruses represent the plant-infecting viruses within the family Bunyaviridae, a virus family further restricted to animals (33). They are propagatively transmitted by a limited number of phytophagous thrips (12). Tomato spotted wilt virus (TSWV), type species of the genus Tospovirus, has an extremely broad host range and has so far economically the greatest impact of all $(12,13)$. Most other tospoviruses, e.g., Iris yellow spot virus (IYSV) (3) and Peanut yellow spot virus (PYSV) (24), have narrow host ranges or, like Impatiens necrotic spot virus (INSV), are mainly restricted to ornamental plants (19).

Tospoviral particles are quasi-spherical, enveloped and contain three single-stranded (ss)RNA segments designated small (S), medium (M), and large (L) RNA. Each RNA segment is tightly packaged by copies of nucleocapsid $(\mathrm{N})$ protein and small amounts of the viral RNA-dependent RNA polymerase (RdRp) (32) forming infectious ribonucleocapsid proteins (RNPs). Due to the presence of inverted complementary repeat sequences at the termini of all tospoviral RNA segments, the RNPs have a pseudocircular appearance (31). As far as investigated, all tospoviruses have ambisense $S$ and M RNAs, only the L RNA being of complete negative polarity. The genomic RNA encodes in viral (v) sense for a suppressor of RNA silencing $\left(\mathrm{NS}_{\mathrm{S}}\right)(29)$ and in viral complementary (vc) sense for the nucleocapsid $(\mathrm{N})$ protein, while the M RNA encodes the cell-to-cell movement protein $\left(\mathrm{NS}_{\mathrm{M}}\right)$ in $\mathrm{v}$ sense and the precursor to the glycoproteins (G1 and G2) in vc sense $(9,10,16)$. The L RNA encodes the putative viral RdRp, also referred to as $\mathrm{L}$ protein (8).

To date, 14 established tospovirus species have been identified based on both biological and molecular ( $\mathrm{N}$ protein sequence) properties $(4,20)$. A few have worldwide distribution, e.g., TSWV and INSV, whereas most others remain restricted to the Eurasian or American continents. So far, the largest diversity of tospoviruses is observed in the eastern part of Asia where nine species can be found, i.e., TSWV, Peanut bud necrosis virus (PBNV), Watermelon silver mottle virus (WSMoV), Watermelon bud necrosis virus (WBNV), PYSV, Peanut chlorotic fanspot virus (PCFV), Melon yellow spot virus (MYSV), IYSV, and a tentative

Corresponding author: R. Kormelink: E-mail address: richard.kormelink@wur.nl

DOI: 10.1094/PHYTO-95-0852

(c) 2005 The American Phytopathological Society species from Gloxinia also found and meanwhile reported from Australia as Capsicum chlorosis virus (CaCV) (20).

TSWV was the first tospovirus reported to occur in tomato cv. Pito Early in Iran, in the Varamin area of Teheran province (1), soon followed by reports of INSV (27) and PBNV (14). Largescale surveys on tospovirus infections have so far not been made and therefore no estimates can be given about the economic impact of tospoviral diseases in Iran. Moreover, the possible occurrence of other tospovirus species in Iran, and even new ones, cannot be excluded. In light of this, a tospo-like virus has very recently been isolated from tomato in the Varamin area during a period coinciding with large thrips infestations. The symptoms on tomato consisted of systemic chlorotic and necrotic spots on leaves and yellow rings on fruits, and the plants generally showed a growth reduction. In a preliminary study, the virus was shown to induce necrotic local lesions on petunia leaves, indicative for the presence of a tospovirus, whereas it did not react with any of the available tospoviral antisera (data not shown). These data suggested the occurrence of a hitherto unknown tomato-infecting species. Here we describe the further characterization of this virus, which indeed turned out to be a novel tospovirus for which the name Tomato yellow ring virus (acronym TYRV) is proposed.

\section{MATERIALS AND METHODS}

Virus isolates and plants. The virus isolate was originally collected from diseased tomato in the Varamin area of Iran in 2002. The virus was transferred from fruits onto Petunia hybrida by mechanical inoculation using $0.01 \mathrm{M}$ phosphate buffer, $\mathrm{pH} 7.0$, containing $0.1 \%$ sodium sulfite. After two passages a single local lesion was isolated and inoculated on Nicotiana benthamiana and maintained by mechanical inoculation. Tospovirus isolates TSWV BR-01 (6), Tomato chlorotic-spot virus (TCSV) BR-03 (6), Groundnut ring-spot virus (GRSV) SA-05 (6), INSV NL-07 (5), WSMoV (Tospo-to) (15), and IYSV-NL (3) used in serological studies, were also maintained on $N$. benthamiana.

For determination of the experimental host range, leaf tissue of TYRV-infected $N$. benthamiana was mechanically inoculated on different host species to compare with those hosts tested for TSWV (Table 1). The plants were kept in the greenhouse under normal day-light conditions or in a light/dark regime of $16 / 8 \mathrm{~h}$ and monitored for 3 to 4 weeks for symptom expression. 
Virus purification, antiserum production, and RNA extraction. Nucleocapsids of TYRV were purified from systemically infected $N$. benthamiana as described by de Ávila et al. (7) but subsequently applied on a 25 to $45 \% \mathrm{CsSO}_{4}$ gradients for further purification. However, a partially purified preparation of the virus was used for electron microscopic observation of the virions in which the specimen was fixed with $1 \%$ glutaraldehyde and stained with $2 \%$ uranyl acetate. For sodium dodecyl sulfate-polyacrylamide gel electrophoresis (SDS-PAGE) analyses of the $\mathrm{N}$ proteins (18), nucleocapsids of IYSV and TSWV were likewise purified.

Nucleocapsid material of TYRV purified from $\mathrm{CsSO}_{4}$ gradients was used to produce a polyclonal antiserum to the $\mathrm{N}$ protein. Rabbits were intradermally immunized by two injections at an interval of 2 weeks with 50 to $100 \mu \mathrm{g}$ of nucleocapsid preparation after emulsification with incomplete Freund's adjuvant (1:1, wt/vol). Blood was collected 2 weeks after the last injection and serum was prepared after overnight incubation of the blood at $4^{\circ} \mathrm{C}$.

Viral RNA of TYRV was extracted from either a semipurified preparation, obtained after centrifugation on a $30 \%$ sucrose cushion, or from a purified nucleocapsid preparation obtained after $\mathrm{CsSO}_{4}$ gradient centrifugation. The RNA was isolated by treatment of nucleocapsids with $1 \%$ SDS followed by phenol/chloroform extraction and ethanol precipitation.

Serological analyses. TYRV was serologically compared with other tospovirus species by a double-antibody sandwich, enzyme- linked immunosorbent assay (DAS-ELISA) (2) using polyclonal antisera directed against the $\mathrm{N}$ protein of each virus. The antisera for TSWV, TCSV, GRSV, and INSV were previously prepared by de Ávila et al. (5), and for IYSV by Cortês et al. (3). Polyclonal anti-N serum for WSMoV (Tospo-to) was supplied by G. Adam (University of Hamburg).

Reverse transcription-polymerase chain reaction cloning and sequence determination. To obtain S RNA-specific clones of TYRV, reverse transcription was performed on purified nucleocapsid RNA using oligonucleotide "Asian Termini” (AT; 5'dCCCGGATCCAGAGCAATCGAGG3') which (in bold) is complementary to the first 8 terminal nucleotides of the $3^{\prime}$ end conserved for all tospoviruses (9), extended with 5 additional nucleotides as found conserved for all Asian tospoviral S RNA segments (data not shown). Reverse transcription (RT) was carried out using Superscript RT (Invitrogen, Carlsbad, CA) or Enhanced Avian RT (Sigma-Aldrich, St. Louis, MO). First-strand cDNA primed by AT was subsequently polymerase chain reaction (PCR)-amplified with primer AT only or in combination with primer UHP (dCACTGGATCCTTTTGTTTTTGTTTTTTG) (4) or P1 (dTCCCGGATCCCYTCATTYCTBCC, complementary to nucleotide 246 to 259 numbered from the $5^{\prime}$ end of the TYRV vRNA strand and containing a conserved sequence from the start codon region of the $\mathrm{NS}_{\mathrm{S}}$ open reading frame (ORF). In a second approach, newly obtained sequences were used to design additional primers that were used in combination with primer AT or UHP to obtain RT-

TABLE 1. Response of several host plants to Tomato yellow ring virus (TYRV) and Tomato spotted wilt virus (TSWV) ${ }^{\mathrm{a}}$

\begin{tabular}{|c|c|c|c|c|}
\hline \multirow[b]{2}{*}{ Host plants } & \multicolumn{2}{|c|}{ TYRV } & \multicolumn{2}{|c|}{ TSWV } \\
\hline & Local reaction & Systemic reaction & Local reaction & Systemic reaction \\
\hline $\begin{array}{l}\text { Amaranthaceae } \\
\text { Gomphrena globosa }\end{array}$ & NL & - & NL & - \\
\hline $\begin{array}{l}\text { Balsaminaceae } \\
\text { Impatiens spp. }\end{array}$ & NL & NS & NL & M,MO,CL,NL \\
\hline $\begin{array}{l}\text { Chenopodiaceae } \\
\text { Chenopodium amaranticolor } \\
\text { Chenopodium quinoa }\end{array}$ & $\begin{array}{l}\text { NL } \\
\text { NL }\end{array}$ & $\begin{array}{l}- \\
-\end{array}$ & $\begin{array}{l}\text { NL } \\
\text { NL }\end{array}$ & $\begin{array}{l}- \\
-\end{array}$ \\
\hline $\begin{array}{l}\text { Compositae } \\
\text { Chrysanthemum sp. } \\
\text { Emilia sonchifolia } \\
\text { Gazania sp. } \\
\text { Zinia elegans }\end{array}$ & $\begin{array}{l}- \\
\mathrm{CS} \\
\mathrm{CS} \\
-\end{array}$ & $\begin{array}{l}- \\
\text { MO } \\
\text { LD,GR } \\
-\end{array}$ & $\begin{array}{l}\text { NS } \\
\text { NL } \\
\text { NL } \\
\text { NL }\end{array}$ & $\begin{array}{c}\text { CS,NS,SN } \\
\text { M,MO,LD } \\
\text { MO } \\
-\end{array}$ \\
\hline $\begin{array}{l}\text { Cucurbitaceae } \\
\text { Cucumis sativus }\end{array}$ & CL & - & CL & - \\
\hline $\begin{array}{l}\text { Liliaceae } \\
\quad \text { Alstroemeria sp. }\end{array}$ & CS & $\mathrm{CS}, \mathrm{C}$ & CS & $\mathrm{MO}, \mathrm{VC}, \mathrm{NS}$ \\
\hline $\begin{array}{l}\text { Solanaceae } \\
\text { Capsicum annum } \\
\text { Datura metel } \\
\text { Datura stramonium } \\
\text { Lycopersicon esculentum cv. Pito Early } \\
\text { Nicotiana benthamiana } \\
\text { Nicotiana clevelandii } \\
\text { Nicotiana glutinosa } \\
\text { Nicotiana rustica } \\
\text { Nicotiana tabacum Samsun } \\
\text { Nicotiana tabacum Samsun NN } \\
\text { Petunia hybrida }\end{array}$ & $\begin{array}{l}\text { CL } \\
\text { CS } \\
\text { CS } \\
\text { CS } \\
\text { CS } \\
\text { CS,NL } \\
\text { NL } \\
\text { NL } \\
\text { NR } \\
\text { CL } \\
\text { NL }\end{array}$ & $\begin{array}{c}- \\
\text { VC,LD } \\
\text { NS,LD } \\
\text { CS,NS,TN,GR } \\
\text { M,LD } \\
\text { VC,LD,PD } \\
\text { LD,PD } \\
- \\
\text { NR,LD } \\
- \\
-\end{array}$ & $\begin{array}{l}\text { NR } \\
\text { CS } \\
\text { CS,NS } \\
\text { CS,NS } \\
\text { CS } \\
\text { CS,NL } \\
\text { NL } \\
\text { NL } \\
\text { NL } \\
\text { NR } \\
\text { NL }\end{array}$ & $\begin{array}{c}\text { MO } \\
\text { M,MO } \\
\text { M,MO } \\
\text { MO,LBP,TN } \\
\text { VC,M,MO,LD } \\
\text { M,MO,LD } \\
\text { M,MO,NS } \\
\text { M,VN } \\
\text { VC } \\
- \\
-\end{array}$ \\
\hline
\end{tabular}

${ }^{a} \mathrm{C}=$ leaf curling, $\mathrm{CL}=$ chlorotic lesions, $\mathrm{CS}=$ chlorotic spots, $\mathrm{GR}=$ growth reduction, $\mathrm{GS}=$ green spots, $\mathrm{LBP}=$ leaf bronzing or purpling, $\mathrm{LD}=$ leaf deformation, $\mathrm{M}=$ mosaic, $\mathrm{LN}=$ leaf necrosis, $\mathrm{MO}=$ mottling, $\mathrm{NL}=$ necrotic lesions, $\mathrm{NR}=$ necrotic rings, $\mathrm{NS}=$ necrotic spots, $\mathrm{SN}=$ stem necrosis, $\mathrm{PD}=$ plant death, $\mathrm{TN}=$ tip necrosis, $\mathrm{VC}=$ veinal chlorosis, $\mathrm{YS}=$ yellow spots, and $-=$ no symptoms . 
PCR fragments covering remaining parts of the S RNA segment. RT-PCR fragments covering the intergenic region were obtained by immunocapture (IC)-RT-PCR (22). To this end, Eppendorf tubes were coated with $50 \mu \mathrm{l}$ of TYRV antisera $(1: 1,000$, vol/vol, of a $1-\mathrm{mg} / \mathrm{ml}$ stock) in coating buffer $(0.05 \mathrm{M}$ Na carbonate, $\mathrm{pH}$

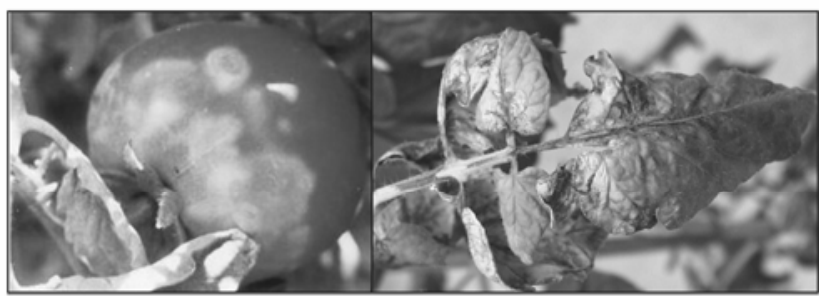

A
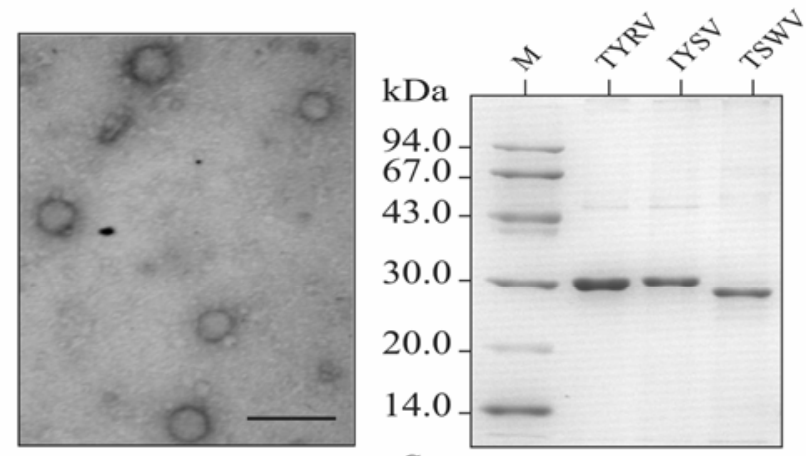

B

$\mathrm{C}$

Fig. 1. Symptoms, virus particles, and $\mathrm{N}$ protein analysis of Tomato yellow ring virus (TYRV). A, Picture shows yellow rings on tomato fruit, chlorosis and necrosis on leaves with leaf stem necrosis; B, Electron micrograph of partially purified TYRV stained with $2 \%$ uranyl acetate, bar represents $200 \mathrm{~nm}$. C, Comparison of nucleocapsid protein of TYRV with those of Iris yellow spot virus (IYSV) and Tomato spotted wilt virus (TSWV) resolved on $15 \%$ sodium dodecyl sulfate polyacrylamide gel and stained with Coomassie brilliant blue. Low molecular weight size markers (M) are indicated at the left of the gel.
9.6) for $2 \mathrm{~h}$ at $37^{\circ} \mathrm{C}$, washed with phosphate-buffered saline containing $0.05 \%$ ( $\mathrm{vol} / \mathrm{vol}$ ) Tween 20 (PBS-T), and subsequently incubated with $50 \mu \mathrm{l}$ of TYRV RNPs for $2 \mathrm{~h}$ at $37^{\circ} \mathrm{C}$. After final removal of the contents, the tubes were washed and immediately used for RT according to the circumstances as described previously. Amplification was done using the Expand Long Template PCR System (Roche Diagnostics, Penzberg, Germany) as previously described by Cortês et al. $(3,4)$. Fragments obtained after PCR were blunt-end cloned into pGEM-T vector (Promega Corp., Madison, WI) and used for nucleotide sequence determination.

DNA sequencing was performed by the dideoxynucleotide chain termination method (25) on an automatic sequence machine (Applied Biosystems, Foster City, CA). Nucleotide and amino acid sequences were compiled and analyzed using BLAST and CLUSTAL W (30). Data from CLUSTAL W were used as input for the construction of a phylogenetic tree using PAUP 3.1.1 package (Illinois Natural History Survey, Champaign, IL) based on 100 replicates and using midpoint rooting (28).

RNA secondary structures were predicted by MFold (34). The panhandle and hairpin structures were predicted on the input of 98 nucleotides (nts) of both terminal ends and 208 nts of the intergenic region, respectively.

The nucleotide sequence for the full-length S RNA of TYRV is accessible as GenBank accession no. AY686718.

Expression of viral $\mathbf{N}$ protein in Escherichia coli. To confirm whether the vcORF of TYRV S RNA codes for the nucleocapsid (N) protein, the vcORF was cloned for expression in E. coli. To this end, a set of specific primers, N1 (dCCCGGATCCATGGCTACCGCACGAGTG) containing an $\mathrm{NcoI}$ site and N2 (dCCCGGATCCGCACTCATTAAAATGCATC) with a BamHI cloning site, was used to RT-PCR amplify the vcORF. The fragment obtained was cloned as an NcoI-BamHI fragment in plasmid pET11t (modified from pET-11d; Novagen, Madison, WI) and transformed into BL21 E. coli cells. Positive clones were induced with isopropyl- $\beta$-thiogalactopyranoside (IPTG) as described by Kormelink et al. (17). Total proteins of induced and noninduced $E$. coli cells were analyzed on $15 \%$ SDS polyacrylamide gel (18),

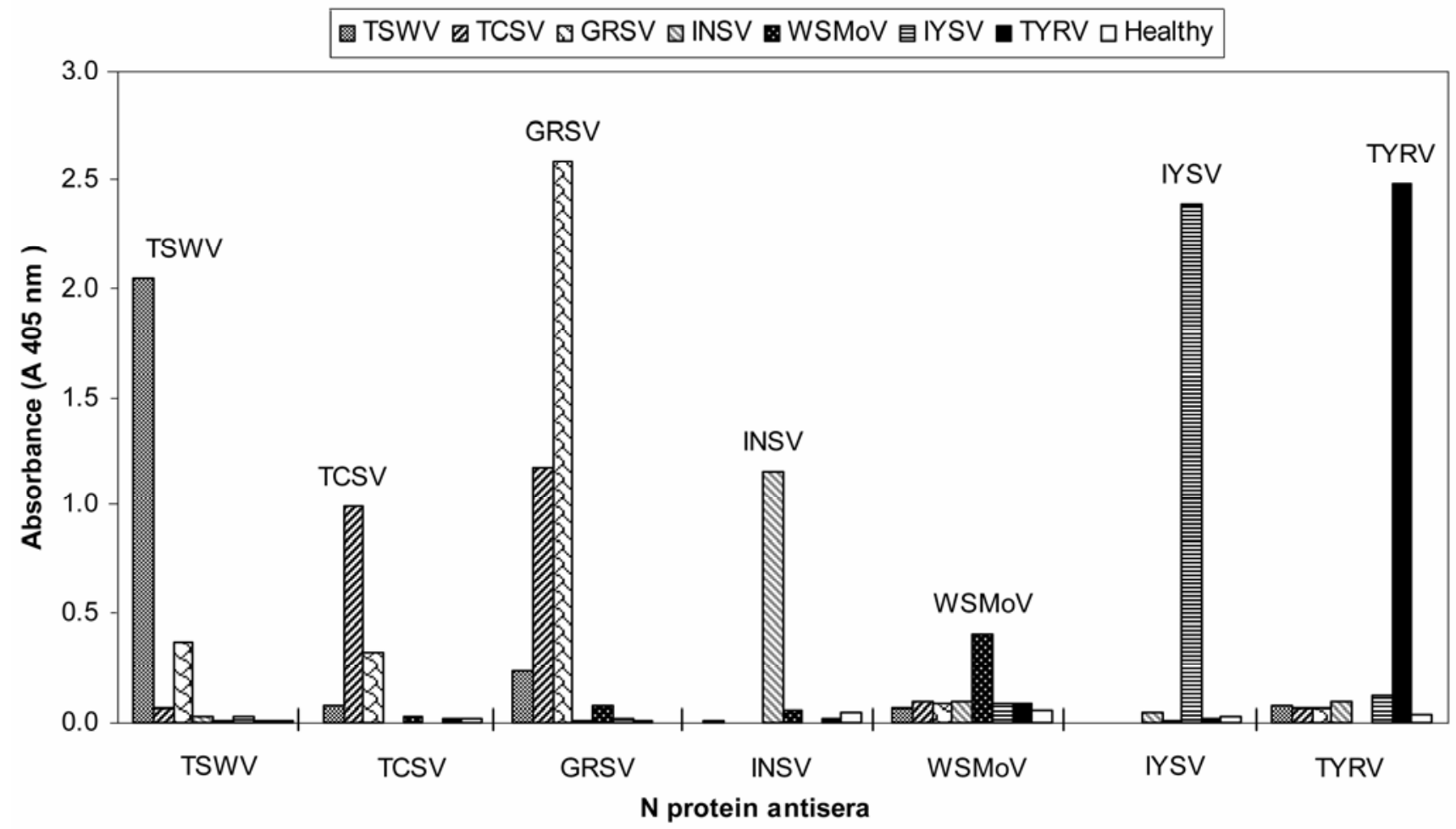

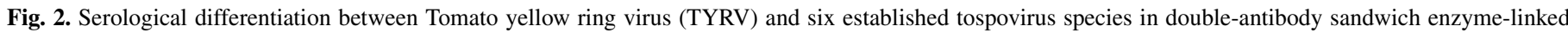
immunosorbent assay format using polyclonal antisera raised against respective $\mathrm{N}$ proteins and the extracts from infected plants as antigen source. 
followed by western immunoblot analysis on Immobilon-P transfer membrane (Millipore Corp., Bedford, MA) using the rabbitproduced anti-TYRV N serum.

\section{RESULTS}

Ultrastructure, host range, and symptomatology. During the tomato-growing season in the Varamin area a number of tomato fields were infected by a putative virus causing necrotic and yellow rings on leaves and fruits, respectively (Fig. 1A). As the symptoms were reminiscent to those of TSWV and thrips were abundant, infected material was serologically tested for the presence of TSWV. Although these tests were negative (data not shown), electron microscopical studies revealed the presence of tospovirus-like particles when partially purified preparations of infected $N$. benthamiana were analyzed (Fig. 1B). As a further step to characterize this potentially new tospovirus, the experimental host range was determined. In approximately half of the hosts tested, a systemic viral infection was observed often initiated after the appearance of chlorotic and/or necrotic local lesions on the inoculated leaves (Table 1). Typical tospovirus symptoms were observed on Petunia hybrida and $N$. benthamiana plants on which necrotic local lesions and chlorotic spots with leaf deformation could be observed, respectively. The virus induced local symptoms on $N$. rustica and Capsicum annuum. No local or systemic symptoms were observed on Zinnia elegans, Arachis hypogea, Phaseolus vulgaris, and Vicia faba. Mechanical backinoculation on Lycopersicon esculentum cv. Pito Early induced chlorosis followed by necrosis on leaves, leaf stem, and top necrosis but plants could recover. After some time fruits developed symptoms that resembled those initially observed on diseased tomato collected from Iran (Fig. 1A). These data indicated that the pathogen was a putative tospovirus causing somewhat distinct symptoms compared to those of TSWV described so far (Table 1).

Serological relationship to other tospoviruses. As a first step towards the production of a polyclonal antiserum against TYRV which would allow serological comparison with other tospovirus species, RNPs were purified, dissociated, and analyzed by SDSPAGE (Fig. 1C). These analyses showed that TYRV $N$ protein (more or less) co-migrated with the $\mathrm{N}$ protein of IYSV and was estimated to be approximately $30 \mathrm{kDa}$. Rabbits were immunized with purified RNPs and serum was collected for the preparation of anti-N immunoglobulin G. Subsequent serological comparison of TYRV with six different tospovirus species in a DAS-ELISA format revealed positive reactions for all homologous combinations (Fig. 2). As expected, additional cross-reactions were observed between TSWV, TCSV, and GRSV, whereas only homologous reactions were observed for INSV, WSMoV, and IYSV. No significant cross-reaction was observed for TYRV with antisera of other tospoviruses and vice versa suggesting that TYRV was serologically distinct from the other tospoviruses tested.

RT-PCR and sequence analysis of the S RNA. In order to obtain the entire S RNA nucleotide sequence several approaches were used. The first RT-PCR reaction was carried out using the primers AT and P1 (described previously), which resulted in a fragment of 259 nts containing $71 \mathrm{nts}$ of the $5^{\prime}$ untranslated region (UTR) and $188 \mathrm{nts}$ of the $\mathrm{NS}_{\mathrm{S}}$ ORF. When the primer combination AT and UHP was used a fragment of 1,152 nts was obtained representing $71 \mathrm{nts}$ of the $3^{\prime}$ UTR sequence, the entire N ORF (825 nts), and $256 \mathrm{nts}$ of the intergenic region. Using newly designed primers, the remaining part of the S RNA was amplified resulting in a full set of RT-PCR clones encompassing the entire (3,061 nts) S RNA segment (Fig. 3A). Since primer AT was only $13 \mathrm{nts}$ in size and could potentially cross-anneal to different positions along all three genomic viral RNAs, the specificity of amplified fragments was verified by restriction enzyme analysis using either the BamHI site within the primers or other restriction sites present in the overlapping sequences. The S RNA sequence obtained was complete, demonstrated by the presence of $5^{\prime}$ and $3^{\prime}$ UTRs containing at least eight residues which are conserved between all tospoviral RNAs (9). The terminal sequences showed long stretches of full complementarity within the first $100 \mathrm{nts}$ potentially involved in pseudo-circularization of the genome segment to form a so-called panhandle structure (Fig. 3B). The viral strand of TYRV S RNA contained an ORF starting with an AUG
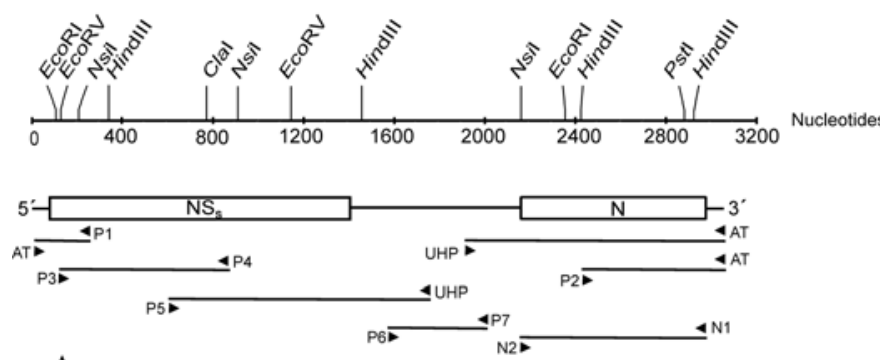

A
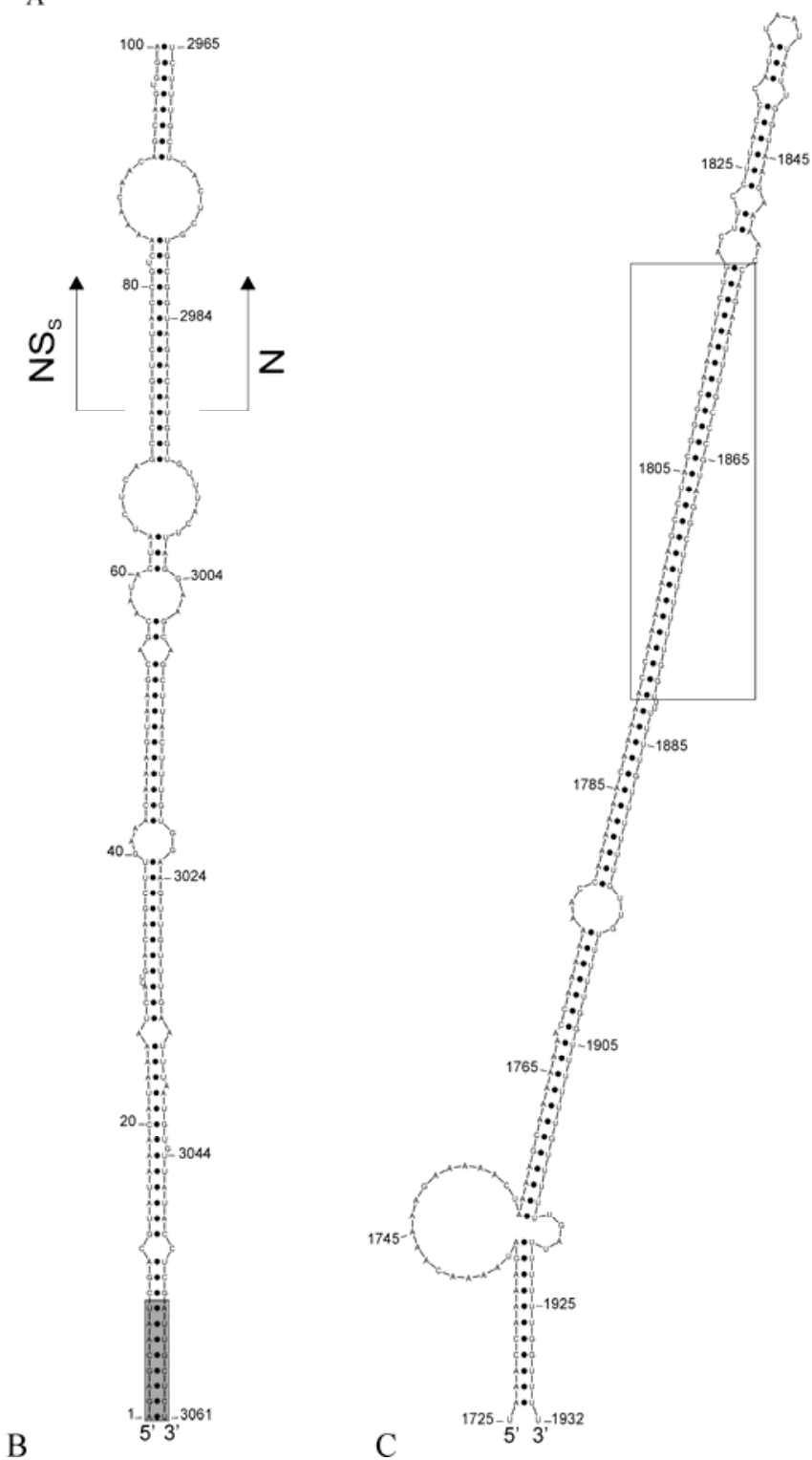

Fig. 3. Cloning strategy of the Tomato yellow ring virus (TYRV) S RNA segment. Schematic representation of the S RNA along a scale bar with a 6 base restriction map. A, Primers (arrowheads) used and DNA fragments (straight lines) obtained from reverse transcription-polymerase chain reaction cloning are indicated. Predicted folding of the $\mathbf{B}$, panhandle and $\mathbf{C}$, hairpin secondary structure of TYRV S RNA. The eight conserved terminal nucleotides are shown in gray. A stretch of 28 nucleotides within the hairpin structure, showing full complementarity, is marked with a box. 
at nucleotide position 72 and terminating with a UGA codon at position 1403 , coding for the $\mathrm{NS}_{\mathrm{S}}$ protein with a predicted $\mathrm{Mr}$ of $50.2 \mathrm{kDa}$. The vcORF coding for the $\mathrm{N}$ protein started with an AUG at nucleotide position 2990 and terminated with a UAA stop codon at nucleotide position 2164 . The $\mathrm{N}$ protein sequence was determined to be 274 residues long with a predicted molecular mass of $30.0 \mathrm{kDa}$. The noncoding intergenic region runs from nucleotide position 1404 to 2165 (Fig. 4) and possesses a high A$\mathrm{U}$ rich content enabling the formation of a stable hairpin. Within this structure a perfect double-stranded RNA (dsRNA) region extending over $28 \mathrm{nts}$ was observed, involving nucleotide residues running from nucleotide positions 1791 to 1818 and 1853 to 1880 (Fig. 3C).

Overall comparison of TYRV S RNA with those of IYSV, MYSV, PBNV, WSMoV, and TSWV revealed that Eurasian tospoviruses contained a $5^{\prime}$ and $3^{\prime}$ UTR with a size between 65 to 71 nts (Fig. 4). For TSWV, 5' and 3' UTRs of 88 and 153 nts were observed, respectively. Sequence alignment of the $5^{\prime}$ UTRs showed first of all a consensus sequence of 8 nts (AGAGCAAU) but, moreover, a conserved sequence motif around nucleotide positions 56 to 71 (AGNAAUACUA(N) $)_{2} \mathrm{UCAGNC}$ ) just upstream of the $\mathrm{NS}_{\mathrm{S}}$ start codon.

Alignment of the 3' UTRs showed that, apart from the first conserved terminal residues, less sequence conservation was observed in comparison to the respective $5^{\prime}$ UTRs (data not shown).

Multiple sequence alignment. To clarify the taxonomic position of TYRV, its $\mathrm{N}$ protein was analyzed by multiple sequence alignment to other tospoviral $\mathrm{N}$ proteins (Table 2). These analyses revealed the highest homology between the TYRV and IYSV $\mathrm{N}$ proteins ( $74 \%$ identity), and much lower homology to the other

\begin{tabular}{|c|c|c|c|c|c|}
\hline & 71 & $\mathrm{NS}_{\mathrm{s}}$ & 762 & $\mathrm{~N}$ & 71 \\
\hline TYRV & $5--$ & 1332(443aa) & & $825(274 a a)$ & - $3^{\prime} 3061$ \\
\hline & 70 & $90 \%$ & 811 & $74 \%$ & 70 \\
\hline YSV & $5--$ & 443aa & & 273aа & -3'3105 \\
\hline
\end{tabular}

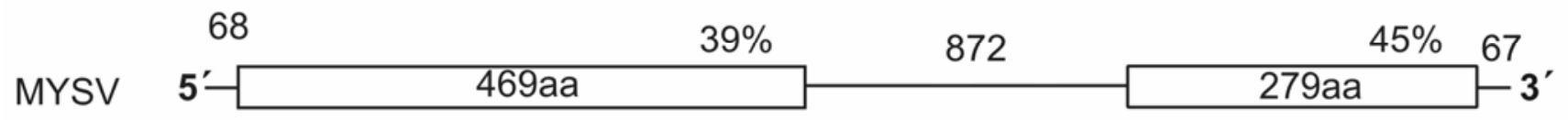
3257

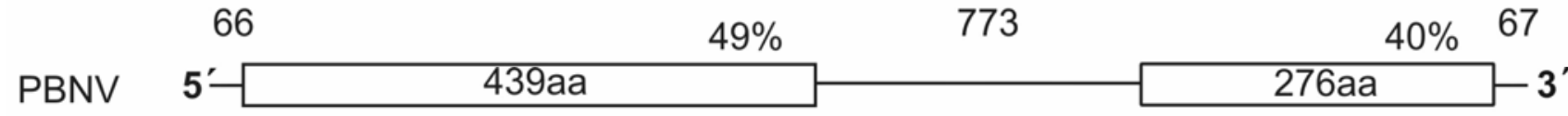
3057

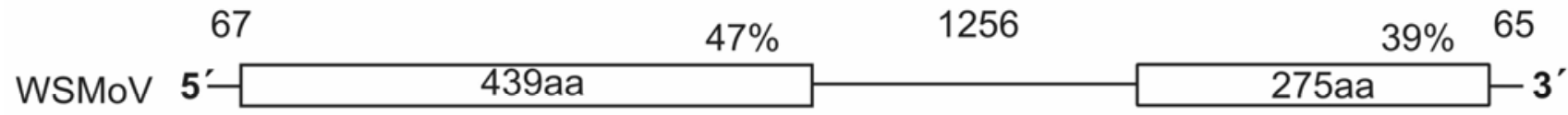
3536

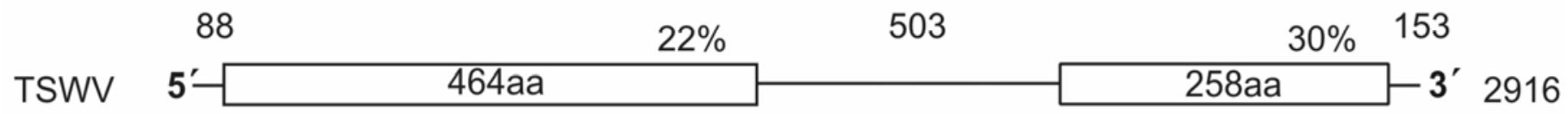

Fig. 4. Topological comparison of the S RNA segment of Tomato yellow ring virus (TYRV) to those of five other tospovirus species. The nucleotide lengths are indicated. The sizes of the $5^{\prime}$ and $3^{\prime}$ untranslated regions and the intergenic regions (in nucleotides) and proteins (in amino acids) are indicated.

TABLE 2. Tospoviral N protein sequence identities (\%)

\begin{tabular}{|c|c|c|c|c|c|c|c|c|c|c|c|c|c|c|c|}
\hline Virus $^{\mathrm{a}}$ & TSWV & TCSV & GRSV & INSV & CSNV & ZLCV & PBNV & WSMoV & WBNV & MYSV & PCFV & PYSV & $\mathrm{CaCV}$ & IYSV & TYRV \\
\hline TSWV & 100 & 77 & 78 & 53 & 75 & 72 & 25 & 28 & 26 & 26 & 18 & 19 & 29 & 30 & 30 \\
\hline TCSV & $\ldots$ & 100 & 81 & 52 & 72 & 71 & 27 & 27 & 26 & 27 & 19 & 20 & 28 & 29 & 31 \\
\hline GRSV & $\ldots$ & $\ldots$ & 100 & 52 & 73 & 75 & 27 & 29 & 28 & 27 & 19 & 19 & 29 & 29 & 31 \\
\hline CSNV & $\ldots$ & $\ldots$ & $\ldots$ & $\ldots$ & 100 & 80 & 26 & 28 & 24 & 29 & 20 & 20 & 28 & 31 & 29 \\
\hline ZLCV & $\ldots$ & $\ldots$ & $\ldots$ & $\ldots$ & $\ldots$ & 100 & 26 & 26 & 26 & 26 & 19 & 19 & 27 & 29 & 29 \\
\hline PBNV & $\ldots$ & $\ldots$ & $\ldots$ & $\ldots$ & $\ldots$ & $\ldots$ & 100 & 86 & 85 & 60 & 21 & 20 & 84 & 42 & 40 \\
\hline WSMoV & $\ldots$ & $\ldots$ & $\ldots$ & $\ldots$ & $\ldots$ & $\ldots$ & $\ldots$ & 100 & 86 & 58 & 20 & 20 & 86 & 41 & 39 \\
\hline PCFV & $\ldots$ & $\ldots$ & $\ldots$ & $\ldots$ & $\ldots$ & $\ldots$ & $\ldots$ & $\ldots$ & $\ldots$ & $\ldots$ & 100 & 59 & 20 & 18 & 17 \\
\hline PYSV & $\ldots$ & $\ldots$ & $\ldots$ & $\ldots$ & $\ldots$ & $\ldots$ & $\ldots$ & $\ldots$ & $\ldots$ & $\ldots$ & $\ldots$ & 100 & 20 & 18 & 20 \\
\hline $\mathrm{CaCV}$ & $\ldots$ & $\ldots$ & $\ldots$ & $\ldots$ & $\ldots$ & $\ldots$ & $\ldots$ & $\ldots$ & $\ldots$ & $\ldots$ & $\ldots$ & $\ldots$ & 100 & 43 & 40 \\
\hline IYSV & $\ldots$ & $\ldots$ & $\ldots$ & $\ldots$ & $\ldots$ & $\ldots$ & $\ldots$ & $\ldots$ & $\ldots$ & $\ldots$ & $\ldots$ & $\ldots$ & $\ldots$ & 100 & 74 \\
\hline TYRV & $\ldots$ & $\ldots$ & $\ldots$ & $\ldots$ & $\ldots$ & $\ldots$ & $\ldots$ & $\ldots$ & $\ldots$ & $\ldots$ & $\ldots$ & $\ldots$ & $\ldots$ & $\ldots$ & 100 \\
\hline
\end{tabular}

a The tospovirus species referred to are as follows: TSWV (D00645); TCSV (S54325); GRSV (S54327); INSV (S400057); CSNV (AF067068); ZLCV (AF067069); PBNV (U27809); WSMoV (Z46419); WBNV (AF045067); MYSV (AF067151); PCFV (AF080526); PYSV (AF013994); CaCV (AY036058); IYSV (AF001387); TYRV in this study. The identities (\%) of the N protein have been calculated from the sequence data using the Vector NTI Suite 6 Program (gap opening penalty 10 and gap extension penalty 0.1 ). 
Eurasian species amongst others, PBNV, WSMoV, WBNV, MYSV, and CaCV (39 to $45 \%$ identity). Whereas the $\mathrm{N}$ proteins showed an overall low homology, a conserved stretch of amino acids was observed around residues 153 and 206 that was restricted to Eurasian tospoviral N sequences (data not shown).

Data from multiple sequence alignments were used as input for the construction of a phylogenetic tree (Fig. 5). The results clearly showed two major clusters, i.e., one containing all (6) tospovirus species that were isolated and primarily distribute in the Americas (Fig. 5, upper branch), and one containing all (9) species that were isolated and primarily distribute in Eurasian (Fig. 5, lower branch). The analyses, furthermore, seemed to point towards a separate clustering of IYSV and TYRV, diverging from the major one consisting of PBNV, WSMoV, WBNV, and MYSV. In conclusion, TYRV was shown to be distinct from all other established tospovirus species and hence should be regarded as a new species.

Expression of the viral $\mathbf{N}$ protein in $\boldsymbol{E}$. coli. To confirm that the vcORF of TYRV S RNA segment indeed coded for the N protein, the vcORF was RT-PCR-amplified with primers N1 and N2, cloned in pET-11t, and subsequently transformed to BL21 E. coli cells for protein induction. The vcORF-encoded protein produced was estimated to be approximately $30 \mathrm{kDa}$. The expressed product specifically reacted with the anti-TYRV serum and co-migrated with $\mathrm{N}$ protein from TYRV RNP preparations (data not shown), confirming the $\mathrm{N}$ protein identity of the vcORF.

\section{DISCUSSION}

Based on host range, symptomatology, ultrastructure, serology, and genomic sequence data, the occurrence of a novel tospovirus in tomato cultivations in Varamin, Iran, has been demonstrated. In view of its disease symptoms in tomato, which were confirmed by back-inoculation experiments on tomato cv. Pito Early, the name Tomato yellow ring virus (TYRV) is proposed. Although the symptoms of TYRV on infected tomato leaves and fruits were similar to those already described for TSWV in the same region (1), no mixed infections with TSWV have been found in collected samples. Next to tomato, TYRV was also detected in naturally infected chrysanthemum (Varamin) and gazania (Teheran) plants as confirmed by DAS-ELISA and nucleotide sequence analysis of the $\mathrm{N}$ gene (data not shown). These results altogether indicate that TYRV has a (experimental/natural) host range that includes agricultural and ornamental crops. Due to the presence of Thrips tabaci in tomato crops during the moment of sample collection, this thrips species may represent a potential vector species of TYRV. Several transmission experiments have been performed in which a range of different thrips species amongst others populations of Frankliniella occidentalis, T. tabaci, and T. palmi have been tested as vector of the virus. However, these analyses have so far failed to identify T. tabaci or other species as vector (data not shown).

The nucleotide sequence of TYRV S RNA showed, as expected, complementarity of the $5^{\prime}$ and $3^{\prime}$ terminal ends allowing formation of a panhandle structure typical for all tospoviral RNA segments (31). The complementarity is $100 \%$ for the first $11 \mathrm{nts}$ with more mismatches between nucleotide 12 up to nucleotide position 100 where the panhandle formation more or less ends (Fig. 3B).

Analysis of the hairpin structure showed a region of dsRNA of 28 nts, which extended to 42 nts when two mismatches were included (Fig. 3C). Recently the 3' terminal ends of TSWV S RNA specific transcripts have been mapped and showed the presence of the hairpin structure in viral transcripts. This suggested that the hairpin may have a function in transcription termination of the viral messenger RNA (I. van Knippenberg, personal communication). The presence of this hairpin and in specific the presence of long stretches of full complementary sequences extending over $28 \mathrm{nts}$ in viral RNA transcripts is interesting in light of dsRNAs triggering the RNA silencing machinery (21). Whether these sequences indeed are the target for the silencing remains to be investigated.

Alignment of the N protein sequence of TYRV with those of 14 other tospoviruses has indicated closest relation to IYSV (74\% identity) and lowest to PCFV (17\% identity) (Table 2). However, alignment of the $\mathrm{NS}_{\mathrm{S}}$ protein sequences of TYRV, IYSV, MYSV, PBNV, WSMoV, and TSWV revealed a greater divergence between the $\mathrm{NS}_{\mathrm{S}}$ proteins (22 to $90 \%$ identity) than those of the respective $\mathrm{N}$ protein sequences (30 to $74 \%$ identity) (Fig. 4).

The phylogenetic analysis (Fig. 5) revealed that tospoviruses, excluding TSWV and IYSV which have apparently further spread by international trading, can be assigned in an American cluster (TSWV, GRSV, TCSV, Chrysanthemum stem necrosis virus [CSNV], Zucchini lethal chlorosis virus [ZLCV], and INSV) and a Eurasian cluster (PBNV, WSMoV, WBNV, CaCV, MYSV, IYSV, TYRV, PYSV, and PCFV). Since TYRV and IYSV are closely related, and the former virus seems endogenous to Iran, a

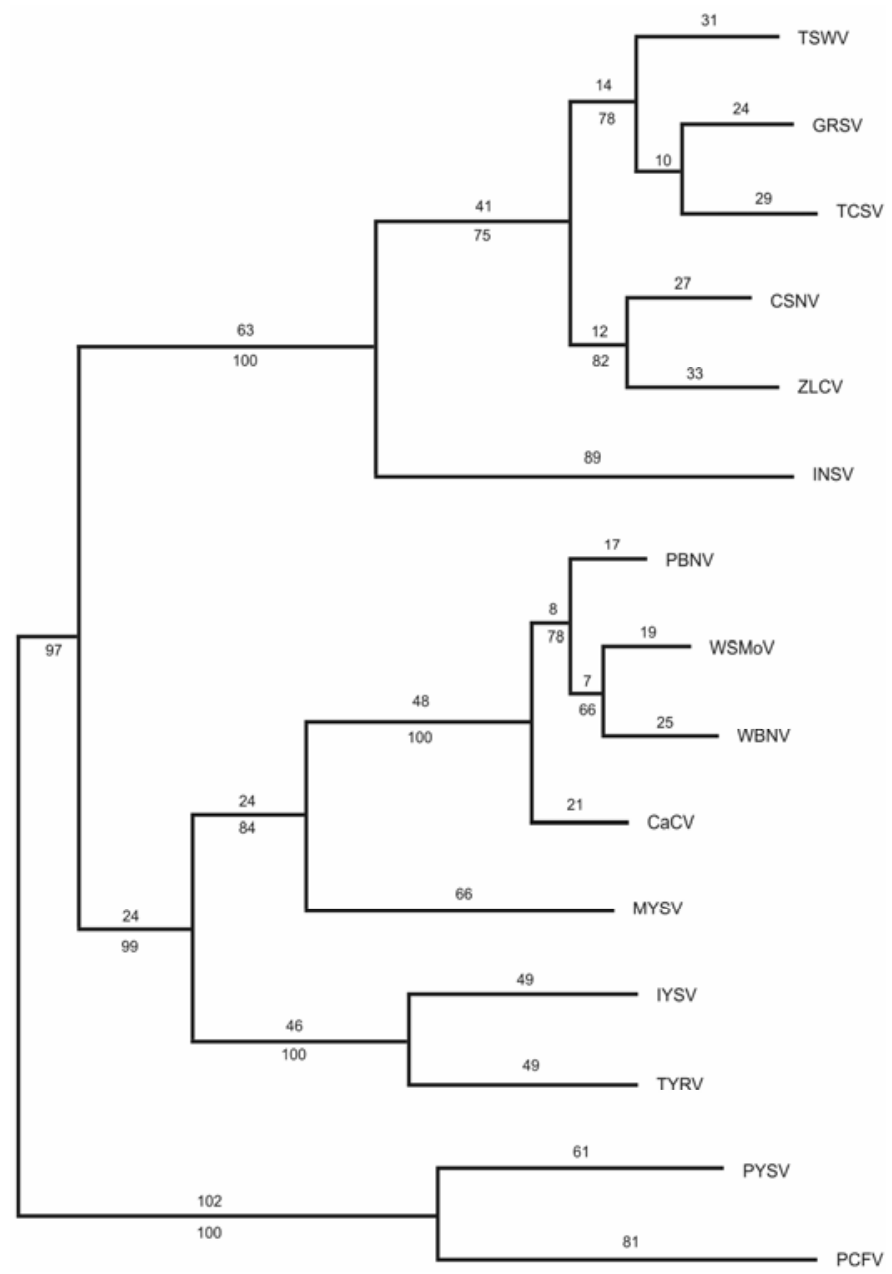

Fig. 5. Phylogenetic tree of different tospovirus species based on $\mathrm{N}$ protein sequence data. The phenogram was constructed using PAUP 3.1.1 (Illinois Natural History Survey, Champaign, IL) from PileUp (Genetics Computer Group, Madison, WI) as input based on 100 replicates using midpoint rooting. Sources of the sequences referred are as follows: Tomato spotted wilt virus (TSWV) (D00645); Tomato chlorotic-spot virus (TCSV) (S54325); Groundnut ring-sport virus (GRSV) (S54327); Impatiens necrotic spot virus (INSV) (S400057); Chrysanthemum stem necrosis virus (CSNV) (AF067068); Zucchini lethal chlorosis virus (ZLCV) (AF067069); Peanut bud necrosis virus (PBNV) (U27809); Watermelon silver mottle virus (WSMoV) (Z46419); Watermelon bud necrosis virus (WBNV) (AF045067); Melon yellow spot virus (MYSV) (AF067151); Peanut chlorotic fanspot virus (PCFV) (AF080526); Peanut yellow spot virus (PYSV) (AF013994); Capsicum chlorosis virus (CaCV) (AY036058); Iris yellow spot virus (IYSV) (AF001387); and Tomato yellow ring virus (TYRV) in this study. 
country that does not play a major role in worldwide agricultural trading yet, it is well possible that both viruses have their origin in the Middle East where IYSV has started to spread all over the world $(3,11,26)$. The existence of a Middle East (sub) clustering of tospovirus species within the large Eurasian cluster would support such a hypothesis. To find this, a more detailed tospovirus survey in the Middle East area is required.

In conclusion, based on the present data TYRV represents the first new tospovirus species isolated from the Middle East. Given the fact that plant virology in this area is still in its infancy, it might be expected that it will not be the last one.

\section{NOTE ADDED}

A highly similar $\mathrm{N}$ protein gene sequence from a tospovirus referred to as Tomato yellow fruit ring virus has been submitted to GenBank by S. Winter and is accessible at accession number AJ493270.

\section{ACKNOWLEDGMENTS}

We thank N. Shahraeen and T. Ghotbi (Plant Pests and Diseases Research Institute, Teheran, Iran) for supplying several virus samples and helpful discussions, D. Shahriary (Agricultural Research Station, Varamin, Iran) for providing pictures of symptoms on tomato, J. Vink (Plant Research International, Wageningen, The Netherlands) and the Laboratory of Phytopathology (Wageningen University, Wageningen, The Netherlands) for assisting in the production of TYRV antisera and providing Vector NTI Suite 6 Program. This work was financially supported by the Dutch Ministry of Agriculture, Nature and Food Quality.

\section{LITERATURE CITED}

1. Bananej, K., Shahraeen, N., Ahoonmanesh, A., Lesemann, D. E., and Shahriary, D. 1998. Identification of Tomato spotted wilt virus from tomato fields in Varamin area. (English abstr.) Iran J. Plant Pathol. 34:3036.

2. Clark, M. F., and Adams, A. N. 1977. Characterization of the microplate method of enzyme linked immunosorbent assay for the detection of plant viruses. J. Gen. Virol. 34:475-483.

3. Cortêz, I., Livieratos, I. C., Derks, A., Peters, D., and Kormelink, R. 1998. Molecular and serological characterization of Iris yellow spot virus, a new and distinct tospovirus species. Phytopathology 88:1276-1282.

4. Cortês, I., Saaijer, J., Wongjkaew, K. S., Pereira, A.-M., Goldbach, R., Peters, D., and Kormelink, R. 2001. Identification and characterization of a novel tospovirus species using a new RT-PCR approach. Arch. Virol. 146:265-278

5. de Ávila, A. C., de Haan, P., Kitajima, E., Kormelink, R., Resende, R. de O., Goldbach, R., and Peters, D. 1992. Characterization of a distinct isolate of tomato spotted wilt virus (TSWV) from Impatiens sp. in the Netherlands. J. Phytopathol. 134:133-151.

6. de Ávila, A. C., de Haan, P., Smeets, M. L. L., Resende, R. de O., Kormelink, R., Kitajima, E., Goldbach, R., and Peters, D. 1992. Distinct levels of relationships between tospovirus isolates. Arch. Virol. 128:211227.

7. de Ávila, A. C., Huguenot, C., Resende, R. de O., Kitajima, E. W., Goldbach, R. W., and Peters, D. 1990. Serological differentiation of 20 isolates of tomato spotted wilt virus. J. Gen. Virol. 71:2801-2807.

8. de Haan, P., Kormelink, R., Resende, R. de O., van Poelwijk, F., Peters, D., and Goldbach, R. 1991. Tomato spotted wilt virus L RNA encodes a putative RNA polymerase. J. Gen. Virol. 71:2207-2216.

9. de Haan, P., Wagemakers, L., Peters, D., and Goldbach, R. 1989. Molecular cloning and terminal sequence determination of the S and M RNAs of tomato spotted wilt virus. J. Gen. Virol. 70:3469-3473.

10. de Haan, P., Wagemakers, L., Peters, D., and Goldbach, R. 1990. The S RNA segment of tomato spotted wilt virus has an ambisense character. J. Gen. Virol. 71:1001-1007.
11. Gera, A., Cohen, J., Salomon, R., and Raccah, B. 1998. Iris yellow spot tospovirus in onion (Allium cepa) in Israel. Plant Dis. 82:127.

12. Goldbach, R., and Kuo, G. 1996. Introduction: Proceedings of the international symposium on tospovirus and thrips of floral and vegetable crops. Acta Hortic. 431:21-26.

13. Goldbach, R., and Peters, D. 1994. Possible causes of the emergence of tospovirus diseases. Semin. Virol. 3:113-120.

14. Golnaraghi, A. R., Pourrahim, R., Shahraeen, N., and Farzadfar, S. 2002. First report of Groundnut bud necrosis virus in Iran. Plant Dis. 86:561.

15. Heinze, C., Maiss, E., Adam, G., and Caspar, R. 1995. The complete nucleotide sequence of the S RNA of a new Tospovirus species, representing serogroup IV. Phytopathology 85:683-690.

16. Kormelink, R., de Haan, P., Meurs, C., Peters, D., and Goldbach, R. 1992. The nucleotide sequence of the M RNA segment of tomato spotted wilt virus, a bunyavirus with two ambisense RNA segments. J. Gen. Virol. 73:2795-2804.

17. Kormelink, R., Storms, M., van Lent, J., Peters, D., and Goldbach, R. W. 1994. Expression and subcellular localization of the $\mathrm{NS}_{\mathrm{M}}$ protein of tomato spotted wilt virus (TSWV), a putative viral movement protein. Virology 200:56-65

18. Laemmli, U. K. 1970. Cleavage of structural proteins during the assembly of the head of bacteriophage T4. Nature 227:680-685.

19. Law, M. D., and Moyer, J. W. 1990. A tomato spotted wilt-like virus with a serologically distinct N protein. J. Gen. Virol. 71:933-938.

20. McMichael, A. L., Perley, D. M., and Thomas, J. E. 2002. A new tospovirus serogroup IV species infecting capsicum and tomato in Queensland, Australia. Australasian Plant Pathol. 31:231-239.

21. Meister, G., and Tuschl, T. 2004. Mechanisms of gene silencing by double-stranded RNA. Nature 431:343-349.

22. Mumford, R. A., and Seal, S. E. 1997. Rapid single immunocapture RTPCR for the detection of two yam potyviruses. J. Virol. Methods 69:7379.

23. Pozzer, L., Bozzerra, I. C., Kormelink, R., Prins, M., Peters, D., Resende, R. de O., and de Ávila, A. C. 1999. Characterization of a tospovirus isolate of Iris yellow spot virus associated with a disease in onion fields in Brazil. Plant Dis. 83:345-350.

24. Reddy, D. V. R., Sudarshana, M. R., Ratna, A. S., Reddy, A. S., Amin, P. W., Kumar, I. K., and Murthy, A. K. 1991. The occurrence of yellow spot virus, a member of tomato spotted wilt virus group, on peanut (Arachis hypogea L.) in India. Pages 77-88 in: Virus-Thrips-Plant Interactions of Tomato spotted wilt virus. H. T. Hsu and R. H. Lawson, eds. Proc. USDA Agric. Res. Serv., ARS-87.

25. Sanger, F., Nicklen, S., and Coulson, A. R. 1977. DNA sequencing with chain-terminating inhibitors. Proc. Natl. Acad. Sci. USA 74:5463-5467.

26. Schwartz, H. F., Brown, W. M., Blunt, T., Jr., and Gent, D. H. 2002. Iris yellow spot virus on onion in Colorado. Plant Dis. 86:560.

27. Shahraeen, N., Ghotbi, T., and Mehraban, A. H. 2002. Occurrence of Impatiens necrotic spot virus in ornamentals in Mahallat and Tehran provinces in Iran. Plant Dis. 86:694.

28. Swofford, D. L. 1993. PAUP: Phylogenetic analysis using parsimony. Version 3.1.1. Computer program distributed by the Illinois Natural History Survey, Champaign, IL.

29. Takeda, A., Sugiyama, K., Nagano, H., Mori, M., Kaido, M., Mise, K., Tsuda, S., and Okuno, T. 2002. Identification of a novel RNA silencing suppressor, $\mathrm{NS}_{\mathrm{S}}$ protein of Tomato spotted wilt virus. FEBS Lett. 532:7579.

30. Thompson, J. D., Higgins, D. G., and Gibson, T. J. 1994. CLUSTAL W: Improving the sensitivity of progressive multiple sequence alignment through sequence weighting, position-specific gap penalties and weight matrix choice. Nucleic Acids Res. 22:4673-4680.

31. van den Hurk, J., Tas, P. W. L., and Peters, D. 1977. The ribonucleic acid of tomato spotted wilt virus. J. Gen. Virol. 36:81-91.

32. van Poelwijk, F., Boye, K., Oosterling, R., Peters, D., and Goldbach, R. 1993. Detection of the L protein of tomato spotted wilt virus. Virology 197:468-470.

33. van Regenmortel, M. H. V., Fauquet, C. M., Bishop, D. H. L., Carstens, E. B., Estes, M. K., Lemon, S. M., Maniloff, J., Mayo, M. A., McGeoch, D. J., Pringle, C. R., and Wickner, R. B. 2000. Virus taxonomy. Pages 599621 in: Seventh Report of the ICTV. Academic Press, New York.

34. Zuker, M. 2003. Mfold web server for nucleic acid folding and hybridization prediction. Nucleic Acids Res. 31:3406-3415. 